\title{
Measurement of women's prenatal attitudes towards maternity and pregnancy and analysis of their predictors
}

\begin{abstract}
BACKGROUND
Research shows that the ability of a woman to adapt to motherhood can be influenced by her attitude towards motherhood and the unborn child during pregnancy. The main goal of the current article is to analyse the maternal attitudes shaped during the prenatal period of the child's development. This goal was associated with fulfilling two research tasks. The first task was to adapt a tool to measure prenatal attitudes towards motherhood and pregnancy to Polish conditions, including some modifications of the tool, and to present the results of that adaptation. The second research task was to investigate selected factors influencing the development of prenatal attitudes.
\end{abstract}

\section{PARTICIPANTS AND PROCEDURE}

The study was carried out in two stages. The first stage of the research, conducted with 227 pregnant women, was to adapt the PRE-MAMA questionnaire. All of the subjects were primiparous women aged between 18 and 39 years $(M=26.84)$, inhabitants of southern Poland. 137 pregnant women from the Silesian Voivodeship in Poland were questioned in the second part of the study. These women were divided into two groups (68 women with a normal course of pregnancy and 69 women with high-risk pregnancies). The mean age of the women approached 30 years $(M=29.78)$

\section{RESULTS}

The results of the first stage of the current research indicate satisfactory psychometric properties of the Kwestionariusz Postaw wobec Macierzyństwa i Ciąży (Polish for: Attitudes towards Motherhood and Pregnancy Questionnaire, abbreviated as PRE-MAMA), composed of 11 statements. Stepwise multiple regression analysis used in the second stage of research revealed that predictors of attitudes towards motherhood and pregnancy include prenatal worries of the pregnant women, planning of the pregnancy and a medical history of miscarriage.

\section{CONCLUSIONS}

Our research points at two important results. First, the PRE-MAMA questionnaire was assessed positively, and it can be stated that this tool can be used in further scientific research concerned with the issues of functioning of pregnant women and their attitudes towards motherhood and pregnancy. Second, the preliminary results suggest, among other things, the importance of fears/concerns, perception of the pregnancy as planned or unplanned as well as previously experienced miscarriages for the formation of women's attitudes towards motherhood and pregnancy.

\section{KEY WORDS}

pregnancy; prenatal period; attitudes; maternity; predictors of attitudes

Organizations - Department of Developmental Psychology and Family Research, Institute of Psychology,

University of Silesia, Katowice, Poland

AUthors' CONTRIBUtion - A: Study design - B: Data collection · C: Statistical analysis - D: Data interpretation ·

E: Manuscript preparation · F: Literature search · G: Funds collection

CORResPonding AUthor - Hanna Przybyła-Basista, Ph.D., Institute of Psychology, University of Silesia, 53 Grażyńskiego Str., 40-126 Katowice, Poland, tel. +48 3235997 16, e-mail: przybyla@us.edu.pl

to Cite this ARTicle - Ilska, M., \& Przybyła-Basista, H. (2014). Measurement and determinants of women's prenatal attitudes towards maternity and pregnancy. Health Psychology Report, 2(3), 176-188. DOI: 10.5114/hpr.2014.45300 


\section{BACKGROUND}

Pregnancy, as a period of adaptation to motherhood and transition into a new role, is a critical period in a woman's development. It brings a lot of changes for the woman, her partner, their relationship, the functioning of the couple as well as the whole family (Wan, Sharp, Howard, \& Abel, 2011; Wan \& Green, 2009).

It is often a difficult and stressful period of transition to parenthood, especially for those who have to prepare for this role for the first time, particularly for the mothers. Prior research suggests that women during this period are more invested in the preparations for the role of a parent (in comparison to men), anticipating larger changes in many areas of their life, such as work, free time, management of their household and relations with others (Pancer, Pratt, Hunsberger, \& Gallant, 2000). Prenatal expectations emerge during pregnancy, the period of preparation for parents' roles. They can be simple or more complex, often filled with romantic ideas of what parenthood might be like (Pancer et al., 2000). It has been previously shown that there is an association between a woman's antenatal psychological state and her adaptation for maternal functioning (Coleman, Nelson, \& Sundre, 1999; Deave, 2005). The theoretical part of this publication aims to describe maternal attitudes shaped in the prenatal period of the child's development. The empirical part has two goals: to present the results of adaptational work on the Attitudes towards Motherhood and Pregnancy (PRE-MAMA) questionnaire, and to answer the question "Which factors can have a significant influence on the development of these attitudes?".

The period of pregnancy can be looked at from two developmental perspectives: first, the prenatal phase of the child's development, its conditions and consequences; and second, the point of view of the development of an adult and fulfilment of the developmental tasks that are characteristic of early (or middle) adulthood. These tasks are connected to entering the new role of a parent, especially that of the mother (Bielawska-Batorowicz, 2012). The prenatal period is therefore a subject of a lot of investigations (cf. Bidzan et al., 2009; Bielawska-Batorowicz, 2006; KornasBiela, 2009). One of the directions of the studies is concerned with the formation of a bond with the unborn child, investigating the factors that determine it and the dynamics of the intensity of the bond throughout the pregnancy (Bidzan, Bieleninik, Zadolska, \& Salwach, 2009; Bieleninik, Preis, \& Bidzan, 2010; Pawlicka, Chrzan-Dętkoś, \& Lutkiewicz, 2013; Mass, Vreeswijk, de Cock, Rijk, \& van Bakel, 2012). Another area of research aims to analyse the factors that have a significant influence on the process of adaptation to motherhood. The attitudes of pregnant women towards motherhood and the unborn child play an important role among the determinants influencing the ability of a woman to adapt to motherhood (Kumar, Robson, \& Smith, 1984; Wan et al., 2011).

Traditionally, we speak about parental attitudes after the child's birth, in the context of upbringing and the developing relationship between parents and children (Ziemska, 1973). The rise of prenatal psychology and reproductive psychology, however, has brought attention to the importance of formation of maternal attitudes, for the development of the mother-child relations during pregnancy and in the early neonatal period (DiPietro, Novak, Costigan, Atella, \& Reusing, 2006; Bor, Brennan, Williams, Najman, \& O’Callaghan, 2003; Kumar et al., 1984; BielawskaBatorowicz, 1999, 2006; Kornas-Biela, 2009). Research shows that prenatal and postnatal attitudes of women towards pregnancy, motherhood and the child have an influence on the subsequent emotional and cognitive development of the child (Hutchinson et al., 2008; Deave, 2005). A negative attitude towards pregnancy and child care is correlated with later health and developmental problems of the child (Bor et al., 2003; Wilkins et al., 2004; Deave, 2005). Moreover, women expressing more negative attitudes towards motherhood and pregnancy assess their children as more difficult (Kumar et al., 1984). There is some evidence that a negative attitude towards pregnancy predicts difficulties in forming a bond with the child after birth (Kokubu, Okano, \& Sugiyama, 2012), increases the risk for postpartum depression (Madar, 2013; Sockol, Epperson, \& Barber, 2014) and can be an indirect cause of low birth weight (Suzuki, Minai, \& Yamagata, 2007).

Previous results suggest that better adaptation to changes during pregnancy has a beneficial influence on the functioning in the role of a parent after the birth; and the adaptational abilities of women for motherhood can influence both their own wellbeing and the development and health of the child (Raphael-Leff, 2010; Wan et al., 2011; Wan \& Green, 2009). Women who experience difficulties preparing for motherhood and entering their new role have specific difficulties during the period after the child birth (Wan et al., 2011; Wan \& Green, 2009). A woman's perceptions of motherhood can be influenced by the inevitability of taking on new challenges and learning new necessary skills, including new duties associated with their new role. Researchers agree that the results of the changes associated with the adaptational period both in normal and high risk pregnancies are complex and multi-faceted. They depend on a number of individual, relational and contextual factors (Coleman, Nelson, \& Sundre, 1999; Dulude, Belanger, Wright, \& Sabourin, 2002).

According to the premises of cognitive models (e.g. Beck's cognitive model), negative beliefs about motherhood can form specific risk factors for perinatal depression and anxiety. In this context, one could treat them as cognitive errors. The beliefs about mother-
Measurement of women's prenatal attitudes towards maternity and pregnancy and analysis of their predictors 
Michalina Ilska, Hanna Przybyła-Basista hood can also mediate the relationships between specific stress inducing factors to which a woman is exposed during pregnancy as well as the early period of parenthood, and the maladaptive emotional responses to certain events (Sockol et al., 2014). The severe stress, to which a pregnant woman may be exposed, associated with the adaptational difficulties, everyday life stress and the situation of a high-risk pregnancy, can feed back to the cognitive assessment of the situation, and hinder the adaptation process. For instance, the tendency to view negative events as uncontrolled is associated with a higher risk of depression. And yet new parents often experience uncontrolled and unexpected events such as a prolonged period of crying or fussiness of a child. There is evidence for an association between maladaptive maternal attitudes and depression during pregnancy and the first year postpartum (Sockol et al., 2014).

Parental attitudes come in to play already during pregnancy, shaping the attitudes towards it and relations with the child in the prenatal period, including the expectations of the child and features attributed to the child (Bielawska-Batorowicz, 1995; Kumar et al., 1984). One can therefore speak of the formation of parental attitudes from the moment of conception. The notion of parenthood includes: an idea of oneself in the role of a parent, conception (initiation of pregnancy), pregnancy, giving birth to the child, its nurturing and upbringing (Adamczak, 1985). The ability of a woman to visualize herself as a mother is an essential part of the psychological process of preparation for parenthood (Deave, 2005). Research shows that there is a difference in this process between women who planned the pregnancy and those who had not. It was more likely that women who had planned their pregnancy had more positive emotions with regards to pregnancy, and were more aware of the changes that it brings (Deave, 2005). Many authors would also stress that the quality and type of parental attitudes are influenced by various factors connected to: the cultural and social environment in which a person grows up; the heritage of the family of origin; individual features (e.g. personality, emotional processes, knowledge, experience, expectations); relational factors - i.e. the quality of marriage; and previous traumatic experiences. The attitudes towards pregnancy and early parenthood are a resultant of general, qualitative developmental changes of psychophysical character, and sociocultural factors (Opozda, 2011).

Attitude is a key concept in our research. It can be defined as an overall assessment of any object. One of the main functions of attitude is organizing knowledge and directing either towards or away from the object of the attitude (Böhner \& Wänke, 2004). According to David G. Myers (2003), attitudes express the reluctant or favourable relation to someone or something, which is manifested in beliefs, emotions or intended actions. Therefore, a tendency to take either a negative or positive stance towards a given object is the essence of an attitude (Wojciszke, 2002). In the context of the current article, pregnancy and motherhood are the objects of a woman's attitude, which can be positive (full of joy and hope) or negative (e.g. anxious). The attitudes of pregnant women towards pregnancy, motherhood and the child - the subject of our analyses - are formed during the prenatal period of child's development. For the purpose of simplification, in the remaining part of the article, we will refer to 'women's attitudes towards motherhood and pregnancy during the prenatal period of child's development' as 'women's prenatal attitudes towards motherhood and pregnancy', or, shortly, 'prenatal attitudes'.

Taking into account the importance of prenatal attitudes of women towards motherhood and pregnancy for the process of adaptation to the new role of mother, it is hard to imagine that the development of research would not include the development of suitable measurement tools. This task was undertaken in the project presented below.

The current study had two goals that were addressed in two stages:

1. The goal of the first stage of the study was to adapt to Polish the Attitudes to Pregnancy and the Baby scale, which is a part of a larger tool used to measure various psychosocial dimensions comprising the adaptation of pregnant women to pregnancy: Maternal Adjustment and Maternal Attitude Questionnaire (MAMA) (Kumar et al., 1984).

2. The goal of the second stage was to determine if and how well the selected factors can predict prenatal attitudes of women towards motherhood and pregnancy.

The results of these research tasks are described below.

\section{THE FIRST STAGE OF RESEARCH THE COURSE OF ADAPTATIONAL WORKS FOR THE ATTITUDES TOWARDS PREGNANCY AND MOTHERHOOD (PRE-MAMA) QUESTIONNAIRE}

\section{DESCRIPTION OF THE ORIGINAL SCALE: MATERNAL ADJUSTMENT AND MATERNAL ATTITUDE QUESTIONNAIRE (MAMA)}

The Maternal Adjustment and Maternal Attitude Questionnaire (MAMA) by Kumar et al. (1984) was developed for the assessment of maternal adjustment and maternal attitudes of pregnant women. It is used to diagnose the adaptation of pregnant women in five dimensions of their psychophysical functioning: body image, somatic symptoms, marital relationship, attitudes to sex and attitudes to pregnancy and the baby. 
MAMA comes in two versions aimed at investigating the adaptation during pregnancy, and after child birth (pregnancy and postnatal version); each of them includes 60 statements (items). The reliability of the questionnaire is satisfactory and was examined using two methods: test-retest and split-half reliability. The comparison of results of the specific subscales with variables collected independently during an interview indicated a satisfactory criterion-related validity.

\section{POLISH LANGUAGE VERSION: ATTITUDES TOWARDS MOTHERHOOD AND PREGNANCY QUESTIONNAIRE (PRE-MAMA)}

Taking into account our subject of research interest concentrated on the attitudes of women towards motherhood and pregnancy, one of the subscales (Attitudes to Pregnancy and the Baby) of the previously described MAMA questionnaire was chosen for adaptation. The original subscale contains 12 statements (items), and according to the premises the results may comprise an important indicator for assessment of the level of adaptation of a woman for pregnancy and motherhood. Each item is rated on a 4-point scale, where 1 means 'not at all' and 4 'very much'. The Attitudes to Pregnancy and the Baby scale had been previously used to assess attitudes of women towards motherhood in the prenatal period of the child's development (Borjesson, 2005; Wan et al., 2011). In the Polish language version the tool had been named Kwestionariusz Postaw wobec Macierzyństwa i Ciaży (PRE-MAMA) ${ }^{1}$ [which will be hereafter referred to in English as: Attitudes toward Maternity and Pregnancy Questionnaire (PRE-MAMA)].

The work on Polish adaptation of the scale was carried out according to standard methodological procedures (Hornowska \& Paluchowski, 2004). The first stage of the adaptational research was to translate the English version into Polish language. Translations were performed by 6 independent translators. Subsequently, a group of 7 researchers fluent in English (6 psychologists and 1 medical doctor specialising in obstetrics and gynaecology) established one common version of the Polish translation. They compared the original English version and the Polish version, which allowed the checking of the accuracy of the final translation (Hornowska \& Paluchowski, 2004).

\section{PARTICIPANTS AND PROCEDURE}

The pilot study was conducted with a group of 227 pregnant women from Southern Poland, sourced in gynaecological clinics. The subjects were informed about the purpose of the study and they expressed consent to take part in it. Suitable procedures were applied in order to ensure the anonymity of subjects.
All of the subjects were primiparous women, aged between 18 and $39(M=26.84, S D=3.46)$. Most of the enquired women were employed $(76.20 \%$ full time and $4.80 \%$ part time), with university level education $(78.00 \%)$, married $(81.90 \%)$ or in informal relationships $(16.80 \%)$. Only 3 of the women were single. The average duration of the respondents' current romantic relationship was 4 years $(M=4.02)$, with standard deviation of $S D=3.39$. Most of the women were in the third $(46.30 \%, n=105)$ or second $(38.30 \%, n=87)$ trimester of pregnancy. The remaining $15.40 \%(n=35)$ of the respondents were in the first trimester of pregnancy. One fifth of the subjects claimed that their pregnancy was unplanned $(19.40 \%, n=44)$, while the remaining women had planned the pregnancy $(80.60 \%, n=183)$. Seventeen and sixty hundredths percent $(n=40)$ of the questioned women had experienced a miscarriage, while $82.40 \%(n=187)$ had had no such experience. One fourth of the respondents mentioned problems with conception $(24.70 \%, n=56)$, while the rest had had no such problems $(75.30 \%$, $n=171)$. Most of them were pregnant women with a normal course of pregnancy $(84.10 \%, n=191)$; $15.90 \%(n=36)$ of women had high-risk pregnancies.

The statistical analysis of the collected results was conducted using SPSS for Windows 21.0 and Statistica 10 software. Exploratory and confirmatory factor analysis as well as Pearson's correlation coefficient (r) was used in the calculations.

\section{Psychometric properties of the tool: factor structure, reliability, validity}

The first step of the statistical analysis was to investigate the factor structure of the PRE-MAMA questionnaire. The value of the Kaiser-Meyer-Olkin (KMO) measure, used to measure sampling adequacy for the 12-item PRE-MAMA scale, was 0.78, which is satisfactory. The result of Bartlett's test of sphericity was statistically significant $\left(\chi^{2}=466.52, d f=55\right.$, $p<.001)$. Both of these results confirmed the appropriateness of factor analysis.

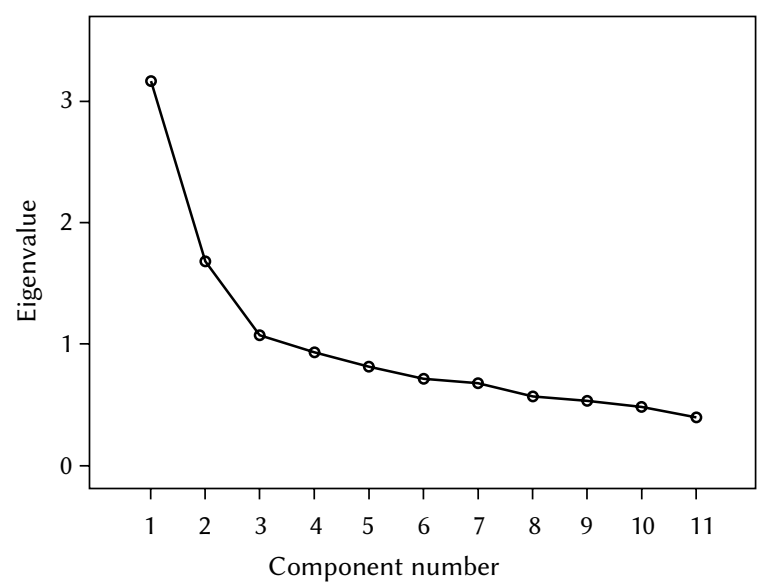

Figure 1. Scree plot - results of factor analysis.
Measurement of women's prenatal attitudes towards maternity and pregnancy and analysis of their predictors 
Table 1

Components of prenatal attitudes towards motherhood and pregnancy - results of factor analysis

Michalina Ilska,

Hanna

Przybyła-Basista

\begin{tabular}{lrr}
\hline \multicolumn{1}{c}{ Items } & Factor loading \\
\cline { 2 - 3 } & \multicolumn{1}{c}{1} & 2 \\
\hline 6. Have you been feeling happy that you are pregnant? & $\mathbf{0 . 7 2 8}$ & 0.119 \\
4. Have you regretted being pregnant? & $\mathbf{0 . 7 1 9}$ & 0.067 \\
5. Has the thought of wearing maternity clothes appealed to you? & $\mathbf{0 . 7 0 1}$ & 0.033 \\
7. Has the thought of having several children appealed to you? & $\mathbf{0 . 6 4 8}$ & 0.072 \\
9. Have you been looking forward to caring for your baby's needs? & $\mathbf{0 . 6 3 2}$ & -0.088 \\
12. Has the thought of breast-feeding your baby appealed to you? & $\mathbf{0 . 5 5 5}$ & -0.103 \\
11. Have you felt that life will be more difficult after the baby is born? & 0.087 & $\mathbf{0 . 6 9 6}$ \\
1. Have you been worrying that you might not be a good mother? & 0.061 & $\mathbf{0 . 6 4 1}$ \\
2. Have you been worrying about hurting your baby inside you? & -0.139 & $\mathbf{0 . 6 3 7}$ \\
3. Has it worried you that you may not have any time to yourself once your & 0.229 & $\mathbf{0 . 6 0 1}$ \\
baby is born? & -0.073 & $\mathbf{0 . 5 6 2}$ \\
10. Have you been wondering whether your baby will be healthy and normal? & $28.80 \%$ & $15.28 \%$ \\
Percent of explained variance & $44.08 \%$ \\
Cumulative percent of explained variance &
\end{tabular}

In order to check the factor structure of the Polish version of the tool, exploratory factor analysis was conducted using the method of principal axes with Oblimin rotation and Kaiser normalisation, assuming a 2 -factor model. The choice of Oblimin rotation allows the obtaining of correlated factors, if they are indeed correlated, while not excluding the possibility of obtaining factors that are not correlated. Both the Kaiser criterion (eigenvalue for each factor is greater than 1), and the scree plot analysis results justified the adoption of a two-factor solution (Figure 1).

The two-factor structure of the Polish version of the 12 -item version of the tool explained $40.28 \%$ of the total variance. Factor one explained $21.16 \%$ of the total variance, and factor two explained $14.12 \%$ of the total variance of the PRE-MAMA questionnaire results. Some problems needing resolving were met during the analysis of item 8 . It was found that this statement ("Have you felt that pregnancy was unpleasant?") had a low discriminating power (0.291) and a relatively low factor loading (0.375), when compared to the rest of the items. Therefore a decision was made to remove the item and rerun the factor analysis.

After assuming a two-factor structure of the tool composed of 11 items, the percent of total explained variance was $44.08 \%$. Factor one, Positive Attitude towards Motherhood and Pregnancy (PRE-MAMA-1), explained $28.80 \%$ of the total variance and contained 6 items (e.g. "Have you been feeling happy that you are pregnant?"; "Have you been looking forward to caring for your baby's needs?"). Factor two, Anxious Attitude towards Motherhood and Pregnancy, explained $15.28 \%$ of the total variance and contained 5 items (e.g., "Have you been worrying that you might not be a good mother?"; "Have you been worrying about hurting your baby inside you?"). The factor structure of the Polish version of the tool and the values of specific factor loadings are presented in Table 1.

Table 2

Psychometric properties of the PRE-MAMA Questionnaire

\begin{tabular}{lccccccc}
\hline \multicolumn{1}{c}{ Scale/subscale } & $N$ (items) & $\alpha$ & $S E M$ & $M$ & $S D$ & Min & Max \\
\hline PRE-MAMA - overall score & 11 & .71 & 0.28 & 20.36 & 4.29 & 11 & 44 \\
$\begin{array}{l}\text { Positive attitude towards motherhood } \\
\text { and pregnancy (PRE-MAMA-1) }\end{array}$ & 6 & .71 & 0.20 & 9.22 & 2.97 & 6 & 24 \\
$\begin{array}{l}\text { Anxious attitude towards motherhood } \\
\text { and pregnancy (PRE-MAMA-2) }\end{array}$ & 5 & .61 & 0.16 & 11.14 & 2.45 & 5 & 20 \\
\hline
\end{tabular}




\begin{tabular}{lccc}
\hline & PRE-MAMA & PRE-MAMA-1 & PRE-MAMA-2 \\
\hline PRE-MAMA & 1 & & \\
PRE-MAMA-1 & $.83^{* *}$ & 1 & \\
PRE-MAMA-2 & $.74^{* *}$ & $.25^{* *}$ & 1 \\
\hline${ }^{* *} p<.010$ & & &
\end{tabular}

Selected psychometric indicators in each of the PRE-MAMA questionnaire subscales were also investigated. The results are presented in Table 2.

Internal reliability calculated using the Cronbach's $\alpha$ method was .71 for the PRE-MAMA-1 subscale and .61 for the PRE-MAMA-2 subscale. It is accepted that an $\alpha$ value of above 70 indicates satisfactory reliability of a scale. However, lower Cronbach $\alpha$ coefficients are accepted if the scale is short or measures heterogeneous indicators (Bedyńska \& Cypryańska, 2013). Discriminating power of the specific items, calculated as a correlation between the result for an item and the overall result for the given subscale, varied between .30 and .53 .

PRE-MAMA stability was assessed in pregnant women who participated in the study twice using the test-retest method, which is one of the methods used to test the reliability of a tool (Hornowska, 2009). The investigation was conducted on a group of 23 pregnant women attending regular checkups in one of the gynaecology clinics in the Silesian Voivodeship in Poland, at an interval of 3 to 4 weeks. The obtained results were satisfactory, as the Pearson correlation coefficient $(r)$ was high, reaching $.87(p=.010)$.

The intercorrelation matrix analysis allowed us to state that the factors were correlated (Table 3 ). The correlations between the specific subscales and the overall score for a scale were statistically significant and high, as expected. Positive correlations also occurred between the subscales, but they were rather low. On one hand, this indicates some level of connection between the subscales, and on the other, some level of their distinction, due to the different contents.

In order to confirm the factor structure of the tool, and to establish a model characterized by the best fit, a confirmatory factor analysis was conducted for the 11-item version (resulting from the removal of item 8). The goodness of fit coefficients for the two-factor solution of the Polish version of PRE-MAMA were as follows: the level of significance for $\chi^{2}=76.89(d f=43$, $p=.001)$, the goodness-of-fit index $(\mathrm{GFI})=0.94$; adjusted goodness of fit index $(\mathrm{AGFI})=0.90$; root mean square error of approximation $(\mathrm{RMSEA})=0.06$. The obtained values for the aforementioned coefficients indicate that the model fits the data well ( $\mathrm{Za}$ krzewska, 2004). Therefore, the confirmatory analysis of factors confirmed a satisfactory fit of the two-fac- tor model composed of 11 items. The assumption of the two-factor model was initially indicated by the exploratory analysis.

One more type of confirmatory analysis was conducted in order to exclude the possibility of assuming a one-factor structure of the PRE-MAMA scale, because in the original questionnaire by Kumar Robson and Smith (1984) the Attitudes to Pregnancy and the Baby subscale has a one-factor structure. The GFI was 0.87 , AGFI $=0.81$, RMSEA $=0.12$, and the level of significance for $\chi^{2}$ test $=153.75(d f=44, p<.001)$. Therefore the results of the confirmatory factor analysis were not satisfactory, and the one-factor model had to be rejected.

The external validity was verified by correlating the results of the PRE-MAMA questionnaire with the results of the Prenatal Maternal Expectations Scale (Polish: Skala Prenatalnych Oczekiwań Macierzyńskich, abbreviated as SPOM-D), developed by Coleman, Nelson, and Sundre (1999) and adapted to Polish by Ilska and Przybyła-Basista (2014). The research leading to the adaptation of SPOM-D to Polish conditions is reported in a separate article (in press). The obtained correlation coefficients indicate a moderately positive correlation $(r=.49, p<.001)$ between the results on the PRE-MAMA and SPOM-D scales. This means that there is a positive correlation between the attitudes towards maternity and pregnancy, and maternal expectations towards the child in the prenatal period of its development (regarding e.g. the health of the child, its looks and character and the facility or difficulties in taking care of it after the birth). This result is in line with our expectations. It confirms that both tools are correlated to a certain degree, and they measure similar properties. Both prenatal expectations and attitudes toward pregnancy and motherhood are regarded by the researchers as variables indicating the cognitive readiness of women to become mothers (Sockol et al., 2014).

\section{DISCUSSION}

The goal of the above reported part of the current study was to adapt one of the scales (Attitudes to Pregnancy and the Baby) that is a part of the multidimensional questionnaire Maternal Adjustment and
Measurement of women's prenatal attitudes towards maternity and pregnancy and analysis of their predictors 
Michalina Ilska, Hanna Przybyła-Basista
Maternal Attitude Questionnaire (MAMA) developed by Kumar et al. (1984) to Polish conditions. As a result we created the Polish version of the tool - Attitudes towards Motherhood and Pregnancy (PRE-MAMA). The reported research indicates that PRE-MAMA is a reliable tool, with good psychometric properties. It is aimed at the investigation of attitudes towards maternity (including attitudes towards the child, caring for the child, and visualisation of self as a future mother) and pregnancy. In the course of the statistical analyses the tool was shortened from 12 to 11 items. The confirmatory factor analysis confirmed the better parameters of fit of the two-factor model containing 11 test items. Two-factor structure of the inventory explained $44.08 \%$ of the total variance. This means that we can relate the results to two dimensions of attitudes of pregnant women in the prenatal period of the child's development: (1) a positive attitude towards motherhood and pregnancy and (2) an anxious attitude towards motherhood and pregnancy.

The results of the current study are partially in line with the findings of Figueiredo, Mendonc, and Sous (2004), who adapted the Maternal Adjustment and Maternal Attitude Questionnaire (MAMA) to Portuguese. Those researchers suggested that the Attitudes to Pregnancy and the Baby scale should be analysed in two different, separate dimensions: attitudes towards pregnancy and attitudes towards the child. Our analyses also suggest the need to differentiate between two factors, though defined differently to the Portuguese study. Our research clearly highlighted the positive and anxious attitudes. This division seems to be logical and in line with the clinical observations of pregnant women, who can have different experiences of pregnancy and preparation for motherhood.

The reliability of both the PRE-MAMA scale as a whole and the Positive Attitude towards Motherhood and Pregnancy subscale is satisfactory. The Cronbach $\alpha$ coefficient for the Anxious Attitude towards Motherhood and Pregnancy subscale is lower than desirable. However, it is important to note that the obtained reliability coefficients are much higher than those obtained by the Portuguese researchers in the course of adaptation of the MAMA questionnaire for the Attitudes to Pregnancy and the Baby scale while adapting the MAMA questionnaire (Figueiredo et al., 2004). The stability of PRE-MAMA results was high, which indicates good reliability of the test-retest type. In terms of the external validity of the questionnaire, it should be noted that although the obtained results were satisfactory, it would be worthwhile to broaden and complement the analysis by studying the correlations between the PRE-MAMA questionnaire and other tools.

\section{THE SECOND STAGE \\ OF THE RESEARCH}

\section{PREDICTORS OF WOMEN'S PRENATAL ATTITUDES TOWARDS MOTHERHOOD AND PREGNANCY}

The second part of the study was aimed at answering the following research questions:

1. Do women with a normal course of pregnancy and those with high-risk pregnancies differ in terms of attitudes towards motherhood and pregnancy?

2. Which of the variables assumed in the model (socio-demographic data, gynaecological and obstetrics data, prenatal fears/concerns of the pregnant women) can predict prenatal attitudes towards motherhood and pregnancy of pregnant women?

There was no hypothesis for the first question due to its exploratory character resulting from the use of PRE-MAMA measurement tool. However, differences were expected between women with a normal course of pregnancy and high-risk pregnancy (cf. Bielawska-Batorowicz, 1995, 2006).

There were four hypotheses for the second question. Two of them were based on previous research (Figueiredo, Tendais, \& Dias, 2014), which had shown that the age and education level can predict prenatal maternal attitudes. The hypothesis about the importance of perceiving the pregnancy as planned or unplanned for the preparation for parenthood was formed on the basis of research by Deave (2005), and the hypothesis about the influence of the level of fears/concerns of the pregnant women on their maternal attitudes in the period of the child's prenatal development was based on research by Sockol et al. (2014).

The following specific hypotheses were formed:

1. Older women have more positive prenatal attitudes towards motherhood and pregnancy.

2. Pregnant women of higher levels of education hold more negative attitudes towards motherhood and pregnancy.

3. Women with unplanned pregnancies are characterised by more negative attitudes towards motherhood and pregnancy.

4. Pregnant women who experience more fears/concerns have more negative attitudes towards motherhood and pregnancy.

\section{PARTICIPANTS AND PROCEDURE}

The study was conducted with 137 pregnant women from the Silesian Voivodeship in Poland. Women were divided into two groups. The first group $(n=68)$ comprised women with a normal course of pregnancy attending medical checkups at a gynaecological clinic. The second group $(n=69)$ consisted of women 
Attitudes towards motherhood and pregnancy - comparison of women with normal and high-risk pregnancies

\begin{tabular}{|c|c|c|c|c|c|c|}
\hline \multirow[t]{2}{*}{ Scale/subscale } & \multicolumn{2}{|c|}{$\begin{array}{c}\text { Normal pregnancy } \\
\qquad n=68\end{array}$} & \multicolumn{2}{|c|}{$\begin{array}{l}\text { High-risk pregnancy } \\
\qquad n=69\end{array}$} & \multirow[t]{2}{*}{$t$} & \multirow[t]{2}{*}{$p$} \\
\hline & $M$ & $S D$ & $M$ & $S D$ & & \\
\hline PRE-MAMA & 20.80 & 4.03 & 20.71 & 3.78 & 0.15 & .883 \\
\hline PRE-MAMA-1 & 9.27 & 2.60 & 9.02 & 2.49 & 0.58 & .566 \\
\hline PRE-MAMA-2 & 11.52 & 11.68 & 11.68 & 2.33 & -0.39 & .696 \\
\hline
\end{tabular}

staying at a hospital ${ }^{2}$ due to high-risk pregnancies. The study took place in 2013 and 2014 and was anonymous. The subjects were informed about the goal of the study and signed consent to take part in it.

Most of the subjects $(77.20 \%)$ were primiparous women, while about one fifth were multiparous $(22.80 \%)$; they were aged between 18 and 39 $(M=29.78, S D=4.25)$. Most of the women were employed $(77.80 \%$ full time and $7.40 \%$ part time), with university level education $(68.10 \%)$, married $(78.80 \%)$ or in informal relationships $(21.20 \%)$. The average time of respondents' current romantic relationships was 4 years $(M=4.02, S D=3.39)$. Most of the questioned women were in the third trimester $(57.90 \%, n=77)$ or second trimester of pregnancy $(32.30 \%, n=43)$. Only $9.80 \%(n=13)$ of the respondents were in the first trimester of pregnancy. For almost one quarter of the subjects the pregnancy was unplanned $(23.50 \%, n=32)$; the rest of the women reported planning the pregnancy $(76.50 \%, n=104)$. Fifteen and fourty hundredths percent women $(n=21)$ had previously experienced a miscarriage, while the rest had had no such experience $(84.60 \%, n=115)$. Almost one third of the respondents reported problems with conception $(29.30 \%, n=39)$; the remaining women had had no such problems $(70.70 \%, n=94)$. About half of the women had a normal course of pregnancy $(49.60 \%, n=66)$, the other half had high-risk pregnancies $(50.40 \%, n=67)$.

The statistical analysis was conducted using SPSS for Windows 21.0 software.

\section{RESULTS}

T-test comparative analysis was used in order to answer the first question - if there are differences between women with high-risk pregnancies and those with a normal course of pregnancy in terms of attitudes towards motherhood and pregnancy. The analysis did not reveal statistically significant differences between the investigated groups, both in terms of the overall results of the PRE-MAMA test, and its subscales: Positive Attitude towards Motherhood and Pregnancy (PRE-MAMA-1) and Anxious Attitude towards Motherhood and Pregnancy (PRE-MAMA-2) (Table 4).
The lack of differences between the women in high-risk and normal pregnancies seems to be an interesting yet surprising result, which will be further discussed in the next part of the article.

A stepwise multiple regression analysis was conducted in order to answer the second research question, regarding the predictors of prenatal attitudes towards motherhood and pregnancy. The following variables were selected as potential predictors of prenatal attitudes towards motherhood and pregnancy: age, marital status, area of residence, education level, number of pregnancies, medical history of miscarriage, perception of the pregnancy as planned or unplanned, hospitalization due to high-risk pregnancy, reported problems with conception, and prenatal fears/concerns. The last variable was measured using the Prenatalne Obawy Cięzarnych - POC questionnaire (Polish for: Prenatal Fears/Concerns of Pregnant Women) used to measure the intensity of fears/concerns of pregnant women associated with the development of the child, developed by Ilska, Ilski, and Kołodziej (article in press). The questionnaire contains 6 items assessed on a 5-level scale, where 4 means 'great concern' and 0 'no concern at all'. The items include assessment of the level of concern with regards to e.g. health of the child or parental competences. High scores indicate high intensity of fears/concerns experienced by pregnant women. The Cronbach $\alpha$ reliability for the scale is .71 .

The results of regression analysis showed that among the explanatory variables included in the regression equation, the prenatal fears/concerns of the pregnant women were the strongest predictor of attitudes towards motherhood and pregnancy (for the overall score of the PRE-MAMA questionnaire) $(\beta=0.45, p=.001)$. The second most significant predictor was the perception of pregnancy as planned or unplanned $(\beta=0.26, p=.002)$, while a previous experience of miscarriage was the third $(\beta=0.17$, $p=.037)$. The selected variables explained $26.00 \%$ of the total variance of the dependent variable. The results of the regression analysis are presented in Table 5.

Further analysis of regression allowed us to distinguish two significant predictors for the variable calculated using the PRE-MAMA-1 subscale. The strongest predictor of a positive attitude towards motherhood
Measurement of women's prenatal attitudes towards maternity and pregnancy and analysis of their predictors 
Table 5

Results of the stepwise multiple regression for PRE-MAMA scale and subscales PRE-MAMA-1 and PRE-MAMA-2

Michalina Ilska, Hanna Przybyła-Basista

PRE-MAMA: Attitudes towards motherhood and pregnancy - overall score $R=.53$, adjusted $R^{2}=.26, F=14.03(3,108), p<.050$

\begin{tabular}{lrrr}
\hline \multicolumn{1}{c}{ Variables } & $B$ & $T$ & $p$ \\
\hline Prenatal fears/concerns of the pregnant women & .45 & 5.52 & $<.001$ \\
Planned vs. unplanned pregnancy & .26 & 3.16 & .002 \\
A medical history of miscarriage & .17 & 2.11 & .037 \\
\hline
\end{tabular}

PRE-MAMA-1: Positive attitude towards motherhood and pregnancy

$R=.39$, adjusted $R^{2}=.13, F=9.52(2,109), p<.050$

\begin{tabular}{llll}
\hline Planned vs. unplanned pregnancy & .35 & 3.94 & $<.001$ \\
Prenatal fears/concerns of the pregnant women & .20 & 2.21 & .029 \\
\hline
\end{tabular}

PRE-MAMA-2: Anxious attitude towards motherhood and pregnancy $R=.60$, adjusted $R^{2}=.35, F=31.33(1,109), p<.050$

\begin{tabular}{lrrr}
\hline Prenatal fears/concerns of the pregnant women & .51 & 6.63 & $<.001$ \\
Level of education & .25 & 3.22 & .002 \\
\hline
\end{tabular}

and pregnancy was whether the pregnancy was planned or unplanned $(\beta=0.35, p=.001)$. Positive attitude towards motherhood and pregnancy was lower for unplanned pregnancies and higher for planned pregnancies. Prenatal fears/concerns of the pregnant women were the second strongest predictor $(\beta=0.20$, $p=.029)$. Both of these variables accounted for $13.30 \%$ of the total variance.

The third regression analysis was concerned with establishing predictors for the variable calculated using the PRE-MAMA-2 subscale. It was found that among the independent variables used in the regression equation, the most significant predictor of an anxious attitude towards motherhood and pregnancy was the prenatal fears and concerns of pregnant women $(\beta=0.51, p=.001)$. The level of education was the second most significant predictor $(\beta=0.25$, $p=.002)$. These two variables accounted for $35.30 \%$ of the total variance. This means that pregnant women experiencing more prenatal fear and concerns had a more anxious attitude towards motherhood and pregnancy. The anxious attitude was also shown to be influenced by level of education - the higher the education, the more anxious the attitude.

\section{DISCUSSION}

Comparative analysis revealed that pregnant women with a normal course of pregnancy and those with high-risk pregnancies had similar attitudes towards motherhood and pregnancy, and the level of risk did not significantly differentiate them in this regard. It is an interesting yet surprising result, as researchers in the prenatal psychology field assume that the occurrence of complications in the course of pregnancy modifies the attitudes of parents towards the child in that period, especially if there is a threat to the child's life and health (cf. Bielawska-Batorowicz, 1995, 2006). However, there is a positive interpretation of this result. It could mean that women in both normal and high-risk pregnancies develop their attitudes towards motherhood and pregnancy based on cues independent of the condition of pregnancy as objectively assessed by a physician. It could be that psychological factors such as the willingness to have a child or the interpretation of risk, etc., play a more important role in the development of these attitudes. Further research and analyses are needed to fully explain this result. First, it would be beneficial to verify it in a larger sample. Second, the reasons for complications in the high-risk pregnancies of women in the hospitalized group should be controlled for. In this study, they were not controlled for, though it might be an important mediating variable.

Another question was concerned with establishing which factors can influence the formation of prenatal attitudes. The following variables were revealed to have a significant importance for prediction of maternal attitudes: the level of fears/concerns of pregnant women, perception of the pregnancy as planned or unplanned, and a medical history of miscarriage. These variables explained $26.00 \%$ of total variance of the dependent variable. On one hand, this result indicates that the selected independent variables do not control the dependent variable to a satisfactory degree and further research should aim to broaden the list of variables included in the model. On the other hand, the value of $R^{2}$ was so large that it is possible to have some degree of confidence in the 
specified predictors of prenatal attitudes (calculated as a total score on the PRE-MAMA scale). What is more, when comparing the percentage of explained variance for the Positive Attitude towards Motherhood and Pregnancy variable (13.30\% for the PRE-MAMA-1 subscale) and the percentage of explained variance for the Anxious Attitude towards Motherhood and Pregnancy (35.30\% for the PRE-MAMA-2 subscale), it is clear that the variables selected for the prediction model explain the anxious attitudes better than the positive attitudes. Future research should therefore focus on broadening the list of variables that could have predictive value for positive attitudes.

The presented research on predictors of components of the prenatal attitudes towards motherhood and pregnancy suggests that multiple fears and concerns that women experience during pregnancy as well as the level of education contribute to an anxious attitude towards motherhood and pregnancy (the more concerns, the more anxious the attitude; the higher the education, the more anxious the attitude). The strongest predictor of a positive attitude towards motherhood and pregnancy was the perception of pregnancy as planned or unplanned. If the pregnancy had been planned, the positive attitude towards motherhood and pregnancy increased; if it had been unplanned, it decreased.

It can be concluded that the researchers' reports are not unanimous about the importance of planning a pregnancy as a predictor of attitudes towards motherhood, accepting pregnancy and functioning as a mother of the unborn child, accepting the child and the development of a bond with the unborn child. Some results indicate no differences in intensity of the bond with the unborn child between women in planned and unplanned pregnancy (cf. BielawskaBatorowicz, 2006). Others show an influence of such planning on the functioning of women in this period (Deave, 2005; Cortés-Salim, González-Barrón, \& Romero-Gutiérrez, 2014; Sockol, Epperson, \& Barber, 2014). Our results, suggesting a significant role of planning as a variable predicting maternal attitudes that are formed in the prenatal period of child's development, should be treated as a contribution to the debate about the importance of this variable.

Taking into account the exploratory character of the research, it is difficult to find another study that would indicate a similar set of variables. However, similar relationships between the selected variables and maternal attitudes were observed in some of the previous analyses. For instance, a study by Sockol et al. (2014) showed that maternal attitudes were a significant predictor of both depressive symptoms and anxiety symptoms (especially the dysfunctional attitudes). Research by Deave (2005) showed that women who had planned their pregnancy assessed it more positively; they experienced positive emotions connected with the pregnancy and were more aware of changes that motherhood might bring. Figueiredo et al. (2014) collected interesting evidence suggesting that negative attitudes to pregnancy and the baby are predicted by higher education. Moreover, age has been shown to play a significant role in the formation of positive maternal attitudes, which meant that the older the women were, the more positive was their attitude towards motherhood and pregnancy. In the latter research project, maternal adjustment and attitudes towards motherhood were compared among adolescent and adult pregnant women (Figueiredo et al., 2014).

It is worth commenting on yet another result. The current study indicated that a previous experience of miscarriage is a predictor of prenatal attitudes towards motherhood and pregnancy, though its significance was rather low $(\beta=0.17, p=.037)$. Our study suggests that an experience of miscarriage is a predictor of a more positive attitude towards pregnancy and future motherhood, which is in some ways surprising. In the attempt to interpret this result we could say that these women exhibit more care for their current pregnancy and the unborn child, which in turn can cause an increase in the positive attitude towards pregnancy and positive visualization of motherhood. However, it needs to be noted that a body of research showed that pregnancy after a miscarriage is a difficult situation for the whole family system (e.g. Côté-Arsenault \& Donato, 2011; cf. Bielawska-Batorowicz, 2006; Kornas-Biela, 2009). Such women were reported to tend to exhibit more anxiety, which results in emotional withdrawal and avoidance of forming a bond with the child too early (Côté-Arsenault \& Donato, 2011). The researchers also pointed out that due to unfavourable past experiences, the woman may adopt an 'ambivalent' attitude towards the next pregnancy, which can result in impairments in the course of developing the bond between her and the child (Hughes, Turton, Hopper, $\&$ McGauley, 2001). These observations are in conflict with the results of our study. The fact that a relatively small number of women who experienced a miscarriage took part in the study and the group was diverse in terms of number and causes of the miscarriages could have led to this discrepancy. Therefore this problem requires further research and analysis.

Reflections upon the presented results should be supplemented by a few remarks about the limitations of the inferences from the current study, as well as some suggestions with regards to the direction of future investigations. Most of all, the study was conducted on a relatively small group of pregnant women $(n=137)$, further divided into two subgroups: women with a normal course of pregnancy $(n=68)$ and women with a high-risk pregnancy $(n=69)$; and the selection of the groups was non-random. In future studies, the number of subjects should be increased, and the selection should be random. Moreover, the 'miscarriage' variable should be more
Measurement of women's prenatal attitudes towards maternity and pregnancy and analysis of their predictors 
Michalina Ilska, Hanna Przybyła-Basista carefully controlled by making a distinction between the causes of miscarriages, which might have an important influence on the psychological functioning of women in further pregnancies, and the process of their adaptation to motherhood.

Including new variables in the model that could significantly explain the formation of a positive attitude towards motherhood and pregnancy (such as optimism, ego-resiliency, support of the partner) should be considered, when looking for predictors of prenatal attitudes towards motherhood and pregnancy. We suggest the extension of the list of independent variables to be included in the prediction model in order to explain both positive and anxious attitudes towards pregnancy. It would also be interesting to further investigate the determinants of prenatal attitudes of women in the risk group (e.g. pregnancies with a risk of child loss, or risks for the mother's health, pregnancies after a miscarriage, or unplanned pregnancies).

\section{CONCLUSIONS}

The presented study revealed several interesting results:

First, psychometric properties of the Prenatal Attitudes towards Motherhood and Pregnancy (PRE-MAMA) questionnaire can be assessed positively. The tool is suitable for further use in scientific research regarding the functioning of women in the prenatal period and assessment of their attitudes towards motherhood and pregnancy. The questionnaire has satisfactory reliability, good stability and validity. A distinction was made between two subscales: Positive Attitude towards Motherhood and Pregnancy (PRE-MAMA-1) and Anxious Attitude towards Motherhood and Pregnancy (PRE-MAMA-2).

Second, no differences were observed between the group of women with a normal course of pregnancy and with a high-risk pregnancy in terms of prenatal attitudes towards motherhood and pregnancy.

Third, the following factors were revealed to have significant importance for predicting maternal attitudes in the prenatal period: level of fears/concerns experienced by women in that period, perception of the pregnancy as planned or unplanned, and a medical history of miscarriage.

Fourth, the conducted research about determinants of prenatal attitudes towards motherhood and pregnancy clearly indicated that variables selected for the prediction model explained the anxious attitudes of pregnant women towards motherhood and pregnancy better than positive attitudes. The following variables were revealed to be statistically significant predictors of anxious attitudes: fears/concerns experienced by women during this period, and a higher level of education. The higher the education level, the more anxious were the attitudes. Positive attitudes were based mostly on the perception of pregnancy as planned or unplanned (the positive attitude diminished if the pregnancy was unplanned and increased if it was planned).

\section{ENDNOTES}

1 Anyone interested in receiving the PRE-MAMA questionnaire can contact the corresponding author at: przybyla@us.edu.pl

2 Clinical Department of Obstetrics and Gynaecology, Silesian Medical Academy in Ruda Śląska, Poland.

\section{References}

Adamczak, B. (1985). Postawa wobec rodzicielstwa - konceptualizacja i konsekwencje badawcze [Attitude towards parenthood - conceptualisation and the consequences for research]. Problemy Rodziny, 3, 8-12.

Bedyńska, S., \& Cypryańska, M. (2013). Zaawansowane metody tworzenia wskaźników - eksploracyjna analiza czynnikowa i testowanie rzetelności skali [Advanced methods for creating indicators exploratory factor analysis and reliability tests for a scale]. In: S. Bedyńska, \& M. Cypryańska (eds.), Statystyczny drogowskaz 1. Praktyczne wprowadzenie do wnioskowania statystycznego [Statistical roadsign 1. Practical introduction to statistical reasoning] (pp. 245-285). Warsaw: Wydawnictwo Akademickie Sedno.

Bidzan, M., Bieleninik, Ł., Zadolska, A., \& Salwach, D. (2009). Bond with a child in the prenatal period in case of prematurely born children. In: K. Turowski (ed.), Wellness and success (pp. 35-54). Lublin: NeuroCentrum.

Bielawska-Batorowicz, E. (1995). Determinanty spostrzegania dziecka przez rodziców w okresie poporodowym [The determinants of perceptions of a child by its parents in the postnatal period]. Łódź: Wydawnictwo Uniwersytetu Łódzkiego.

Bielawska-Batorowicz, E. (2006). Psychologiczne problemy prokreacji [Psychological problems of procreation]. Katowice: Śląsk Wydawnictwo Naukowe.

Bielawska-Batorowicz, E. (2012). Znaczenie badań nad wybranymi psychologicznymi aspektami prokreacji [The importance of research on selected psychological aspects of procreation]. Psychologia Wychowawcza, 1-2, 7-21.

Bieleninik, Ł., Preis, J., \& Bidzan, M. (2010). Uwarunkowania więzi emocjonalnej z dzieckiem w okresie prenatalnym w ciążach wielopłodowych i pojedynczych [The determinants of the emotional bond with a child in the prenatal period in multi- 
ple and single pregnancies]. Perinatologia, Neonatologia i Ginekologia, 3, 223-231.

Böhner, G., \& Wänke, M. (2004). Postawy i zmiana postaw [Attitudes and attitude change]. Gdańsk: Gdańskie Wydawnictwo Psychologiczne.

Bor, W., Brennan, P. A., Williams, G. M., Najman, J. M., \& O'Callaghan, M. A. (2003). Mother's attitude towards her infant and child behavior five years later. Australian and New Zealand Journal of Psychiatry, 37, 748-755.

Borjesson, K. (2005). Mental illness: relation to childbirth and experience of motherhood. Retrived from http://diss.kib.ki.se/2005/91-7140-521-6/thesis.pdf.

Coleman, P., Nelson, E. S. \& Sundre, D. L. (1999). The relationship between prenatal expectation and postnatal attitudes among first-time mothers. Journal of Reproductive and Infant Psychology, 17, 26-39.

Cortés-Salim, P., González-Barrón, M., \& RomeroGutiérrez, G. (2014). Psycho-emotional disorders in women with unplanned pregnancies. American Journal of Health Research, 2, 27-32.

Côté-Arsenault, D., \& Donato, K. (2011). Emotional cushioning in pregnancy after perinatal loss. Journal of Reproductive and Infant Psychology, 29, 81-92.

Deave, T. (2005). Associations between child development and women's attitudes to pregnancy and motherhood. Journal of Reproductive and Infant Psychology, 23, 63-75.

DiPietro, J. A., Novak, M. F., Costigan, K. A., Atella, L. D., \& Reusing, S. P. (2006). Maternal psychological distress during pregnancy in relation to child development at age two. Child Development, 77, 573-587.

Dulude, D., Belanger, C., Wright, J., \& Sabourin, S. (2002). High-risk pregnancies, psychological distress, and dyadic adjustment. Journal of Reproductive and Infant Psychology, 20, 101-123.

Figueiredo, B., Mendonca, M., \& Sousa, R. (2004). Portuguese version of the Maternal Adjustment and Maternal Attitudes (MAMA). Psicologia Saúde \& Doenças, 5, 31-51.

Figueiredo, B., Tendais, I., \& Dias, C. C. (2014). Maternal adjustment and maternal attitudes in adolescent and adult pregnant women. Journal Pediatric and Adolescent Gynecology, 27, 194-201.

Hughes, P., Turton, P., Hopper, E., \& McGauley, G. (2001). Disorganized attachment behavior among infants born subsequent to stillbirth. Journal of Child Psychology and Psychiatry, 42, 791-801.

Hornowska, E., \& Paluchowski, W. J. (2004). Kulturowa adaptacja testów psychologicznych [Cultural adaptation of psychological tests]. In: J. Brzeziński (ed.), Metodologia badań psychologicznych. Wybór tekstów [Methodology of psychological research. A selection of texts] (pp. 151-191). Warsaw: Wydawnictwo Naukowe PWN.

Hornowska, E. (2009). Testy Psychologiczne. Teoria i Praktyka [Psychological tests. Theory and Practice]. Warsaw: Scholar Wydawnictwo Naukowe.
Hutchinson, D. M., Alati, R., Najman, J. M., Mattick, R. P., Bor, W., O'Callaghan, M., \& Williams, G. M. (2008). Maternal attitudes in pregnancy predict drinking initiation in adolescence. Australian and New Zealand Journal of Psychiatry, 42, 324-334.

Ilska, M., \& Przybyła-Basista, H. (2014). Rola oczekiwań wobec dziecka w okresie prenatalnym $w$ określaniu dobrostanu kobiet $w$ ciąży [The role of expectations towards the child in the prenatal period in the assessment of pregnant women's wellbeing]. Referat na XXIII Ogólnopolskiej Konferencji Psychologii Rozwojowej: Zmiany rozwojowe w biegu życia: konteksty i perspektywy [Seminar paper for the XXIII Polish Conference in Developmental Psychology: Developmental changes in the course of life: contexts and perspectives]. Lublin, 28-30 maja 2014 r.

Kokubu, M., Okano, T., \& Sugiyama, T. (2012). Postnatal depression, maternal bonding failure, and negative attitudes towards pregnancy: a longitudinal study of pregnant women in Japan. Archives of Women's Mental Health, 15, 211-216.

Kornas-Biela, D. (2009). Pedagogika prenatalna. Nowy obszar nauk o wychowaniu [Prenatal pedagogics. A new area in education sciences]. Lublin: Wydawnictwo KUL.

Kumar, R., Robson, K. M., \& Smith, A. M. R. (1984). Development of a self-administred questionnaire to measure maternal adjustment and maternal attitudes during pregnancy and after delivery. Journal of Psychosomatic Research, 28, 43-51.

Madar, A. (2013). Maternal Attitudes and Beliefs Scale: Development and Piloting. Procedia - Social and Behavioral Sciences, 78, 415-419.

Mass, A. J., Vreeswijk, C. M., de Cock, E. S., Rijk, C. H., \& van Bakel, H. J. (2012). "Expectant Parents": Study protocol of a longitudinal study concerning prenatal (risk) factors and postnatal infant development, parenting, and parent-infant relationships. BMC Pregnancy and Childbirth, 12, 46. Retrived from http://www.biomedcentral.com/1471-2393/12/46.

Myers, D. G. (2003). Psychologia spoteczna [Social Psychology]. Poznań: Wydawnictwo Zysk i S-ka.

Opozda, D. (2011). Stan błogosławiony czy ciężar? - z psychopedagogicznej problematyki postaw wobec "wczesnego rodzicielstwa". Uwagi wybrane [A blessed state or a burden? - from the psychopedagogical issues of attitudes towards 'early parenthood'. Selected notes]. In: E. Lichtenberg-Kokoszka, J. Dzierżanowski, \& E. Janiuk (eds.), Ciaża czy stan błogosławiony? Zagadnienie interdyscyplinarne [Pregnancy or a blessed state? Interdisciplinary issues] (pp. 41-55). Cracow: Wydawnictwo Impuls.

Pancer, S. M., Pratt, M., Hunsberger B., \& Gallant, M. (2000). Thinking ahead: Complexity of expectations and the transition to parenthood. Journal of Personality, 68, 253-280.
Measurement of women's prenatal attitudes towards maternity and pregnancy and analysis of their predictors 
Michalina Ilska,

Hanna

Przybyła-Basista
Pawlicka, P., Chrzan-Dętkoś, M., \& Lutkiewicz, K. (2013). Prężność psychiczna przyszłych matek oraz kolejność budowania więzi z nienarodzonym jeszcze dzieckiem [Resilience of expectant mothers and order of pregnancy as moderators of mother-fetal attachment]. Family Forum, 3, 139-152.

Raphael-Leff, A. (2010). Mothers' and fathers' orientations: patterns of pregnancy, parenting and the bonding process. In: S. Tyano, M. Keren, H. Herman, \& J. Cox (eds.), Parenthood and Mental Health: A Bridge between Infant and Adult Psychiatry (pp. 9-22). Oxford: John Wiley \& Sons, Ltd.

Sockol, L. E., Epperson, C. N., \& Barber, J. P. (2014). The relationship between maternal attitudes and symptoms of depression and anxiety among pregnant and postpartum first-time mothers. Archives of Women's Mental Health, 17, 199-212.

Suzuki, K. K., Minai, J., Yamagata, Z. (2007). Maternal negative attitudes towards pregnancy as an independent risk factor for low birth weight. Journal of Obstetrics and Gynecology Research, 33, 438-444.

Wan, M. W., \& Green, J. (2009). The impact of maternal psychopathology on child-mother attachment. Archives of Women's Mental Health, 12, 123-134.

Wan, M. W., Sharp, D. J, Howard, L. M., \& Abel, K. M. (2011). Attitudes and adjustment to the parental role in mothers following treatment for postnatal depression. Journal of Affective Disorders, 131, 284-292.

Wilkins, A. J., O'Callaghan, M. J., Najman, J. M., Bor, W., Williams, G. M., \& Shuttlewood, G. (2004). Early childhood factors influencing health-related quality of life in adolescents at 13 years. Journal of Pediatrics Child Health, 40, 102-109.

Wojciszke, B. (2002). Człowiek wśród ludzi. Zarys psychologii spotecznej [An individual among people. The outline of social psychology]. Warszawa: Wydawnictwo Naukowe Scholar.

Zakrzewska, M. (2004). Konfirmacyjna analiza czynnikowa w ujęciu pakietu statystycznego LISREL 8.51 (2001) Karla G. Joreskoga i Daga Sorboma. [Confirmatory analysis in the context of LISREL 8.51 (2001) statistical package by Karl G. Joreskog and Dag Sorbom]. In: J. Brzeziński (ed.), Metodologia badań psychologicznych. Wybór tekstów [Methodology of psychological research. A selection of literature] (pp. 442-478). Warsaw: Wydawnictwo Naukowe PWN.

Ziemska, M. (1973). Postawy rodzicielskie [Parental attitudes]. Warsaw: Wiedza Powszechna. 